\title{
Performance of phosphonates as copper(II) ions stabilization agents for industrial water systems
}

\author{
Z. Amjad \\ Walsh University, School of Arts and Sciences, North Canton, OH 44720, USA \\ E-mail:zamajad@walsh.edu
}

\begin{abstract}
Copper(II) salts have long been used to kill algae in water systems, but they can precipitate as insoluble salts and form deposits on equipment surface. It is important to remove toxic metal from industrial waste because of contamination and toxicity issues. This paper discusses the testing and effects of various phosphonates to control copper-based fouling in the industrial water systems. It has been found that $\mathrm{Cu}$ (II) ions stabilization (complexation, precipitation, dispersion, etc.) strongly depends on solution $\mathrm{pH}$, reaction time, and phosphonate concentration. Results on the evaluation of various phosphonates suggest the following order, in terms of decreasing effectiveness: HEDP $\approx$ HPA $>$ PAPEMP $>$ AMP $>>$ PBTC.
\end{abstract}

Keywords: copper(II), precipitation, inhibition, stabilization, dispersion, phosphonates.

Received: January 4, 2015.

doi: 10.17675/2305-6894-2015-4-1-075-084

\section{Introduction}

Corrosion in industrial water systems can be controlled by using inhibitors which are selected based on the metallurgy. All types of metals under harsh or stressed conditions can be corroded and be susceptible to microbiological attack, fouling, and scale formation. Since different metals corrode for different reasons, it is therefore important to keep in mind the metallurgy present while developing a treatment program with inhibitors that are effective in controlling all potential corroding surfaces. Typical corrosion products include oxides and hydroxides of aluminum $\left(\mathrm{Al}^{3+}\right)$, copper $\left(\mathrm{Cu}^{2+}\right)$, iron $\left(\mathrm{Fe}^{3+}\right)$, and zinc $\left(\mathrm{Zn}^{2+}\right)$. Common corrosion inhibitors include polyphosphate, phosphonate, phosphono citrate, benzotriazole, tolyltriazole, and molybdate.

Among the various dissolved impurities present in natural water, metal ions including aluminum, copper, iron, manganese, and zinc when present at low concentrations (e.g., few parts per million, ppm) pose the most serious problems in many domestic and industrial applications. These metal ions will not only form insoluble hydroxide under acid and/or alkaline $\mathrm{pH}$ conditions and deposit on equipment surfaces but will also influence the performance of scale inhibitors and dispersants commonly used in water treatment formulations. The presence of soluble impurities such as biocides, cationic polymeric flocculants/coagulants, and metal ions present in cooling waters have been known to impact the performance of polymeric scale inhibitors. Hamdona et al. [1] investigated the 
kinetics of gypsum precipitation in the presence of divalent metal ions and reported that $\mathrm{Mg}^{2+}$ is a better gypsum inhibitor than $\mathrm{Fe}^{2+}$ probably due to the formation of $\mathrm{MgSO}_{4}$ ion pairs. In contrast, Weignen et al. [2] found that $1 \mathrm{mM}(63 \mathrm{mg} / \mathrm{L}) \mathrm{Cu}^{2+}$ or $\mathrm{Zn}^{2+}(65 \mathrm{mg} / \mathrm{L})$ enhanced crystal growth rate of gypsum. Amjad and his coworkers [3] studied the influence of recirculating water system impurities on the calcium phosphate inhibiting polymers. It was shown that manganese and copper ions are antagonistic to the performance of acrylate-based polymers but the adverse impact is not as great as with $\mathrm{Fe}^{3+}$. Recently, Ahmad et al. [4] investigated the performance of various additives (e.g., sodium salt of aminotris(methylene phosphonate), sodium tripolyphosphate, sodium polyacrylate, a blend of polycarboxylate and phosphonate) as gypsum scale inhibitors. Results of this study reveal that gypsum scale inhibition strongly depends on the concentration and the type of inhibitor tested. Among the various additives tested, polyacrylate exhibits the best performance. In another study by Shih et al. [5], it was reported that trace levels of $\mathrm{Al}^{3+}$ exhibits significant antagonistic effect on the performance of various gypsum scale inhibitors.

Removal of heavy metals from industrial wastewater is of primary importance because they are not only causing contamination of water bodies but are also toxic to many life forms [6]. Industrial processes such as paint manufacturing, printed circuit board manufacturing, metal polishing, and wood preservatives generate wastewater containing heavy metal contaminants. Since most of the heavy metals are non-degradable into non-toxic end products, their concentrations must be reduced to acceptable levels before discharging them into environment. Otherwise, these could pose threats to public health or affect aesthetic quality of potable water. Over the years, various types of methods have been developed to remove toxic metals from aqueous streams. These approaches include precipitation, coagulation, ion-exchange, adsorption, and membrane based filtration processes.

Copper(II) or $\mathrm{Cu}^{2+}$ salts have been used for decades to kill algae in water systems such as swimming pool and spas. Unfortunately, $\mathrm{Cu}^{2+}$ can easily precipitate as in alkaline or near alkaline water conditions and also in oxidizing conditions [7]. Further, in these environments $\mathrm{Cu}^{2+}$ can precipitate as the insoluble hydroxide, oxide, and/or carbonate salts. Precipitation of these copper salts not only reduces the biocidal activity of the $\mathrm{Cu}^{2+}$ in solution but also may deposit as insoluble salts onto the swimming pool surfaces as an unattractive blue or black stain that is difficult to remove. Figure 1 presents an example of corroded copper tube.

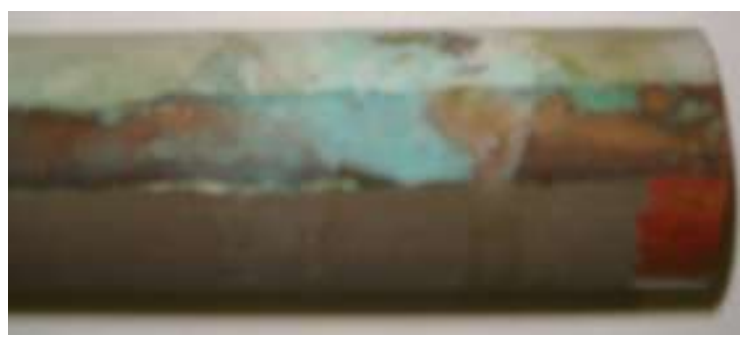

Figure 1. Copper corroded tube. 
In our previous investigations, we reported the influence of various polymeric and non-polymeric additives as stabilization agents for divalent and trivalent metal ions. It was shown that the stabilization of metal ions (e.g., $\mathrm{Cu}^{2+}, \mathrm{Zn}^{2+}, \mathrm{Mn}^{2+}, \mathrm{Al}^{3+}, \mathrm{Fe}^{3+}$ ) depends on the additive concentration and additive architecture $[8,9]$. This paper is concerned with the influence of organophosphorous compounds commonly used in water treatment formulation for corrosion and scale control, as $\mathrm{Cu}^{2+}$ stabilizing agents for cooling and process waters. Table 1 shows the composition, functional group, molecular weight (MW) and acronyms for the phosphonates tested.

Table 1. Phosphonates studied.

\begin{tabular}{|c|c|c|c|c|}
\hline Phosphonate & Structure & $\begin{array}{c}\text { Functional Group } \\
\text { Ionic Charge }\end{array}$ & $\begin{array}{c}\text { Molecular } \\
\text { Weight }\end{array}$ & Acronym \\
\hline $\begin{array}{l}\text { Hydroxyphosphono } \\
\text { acetic acid }\end{array}$ & $\mathrm{O}=\left.\left.\right|_{\mathrm{OH}} ^{\mathrm{P}}\right|_{\mathrm{OH}} ^{\mathrm{OH}}-\mathrm{COOH}$ & $\begin{array}{l}-\mathrm{COOH} \\
-\mathrm{OH} \\
-\mathrm{PO}_{3} \mathrm{H}_{2} \\
\text { Negative }\end{array}$ & 156 & HPA \\
\hline $\begin{array}{l}\text { Aminotris(methylene } \\
\text { phosphonic acid) }\end{array}$ & $\begin{array}{c}\mathrm{CH}_{2} \mathrm{PO}_{3} \mathrm{H}_{2} \\
\stackrel{\mathrm{N}}{-\mathrm{CH}_{2} \mathrm{PO}_{3} \mathrm{H}_{2}}-\mathrm{PO}_{3} \mathrm{H}_{2}\end{array}$ & $\begin{array}{l}-\mathrm{PO}_{3} \mathrm{H}_{2} \\
\text { Negative }\end{array}$ & 299 & AMP \\
\hline $\begin{array}{l}\text { 1-hydroxyethylidine } \\
\text { 1,1-diphosphonic acid }\end{array}$ & $\mathrm{H}_{2} \mathrm{PO}_{3}-\underset{\mathrm{CH}_{3}}{\mathrm{CH}}-\mathrm{PO}_{3} \mathrm{H}_{2}$ & $\begin{array}{c}-\mathrm{OH} \\
-\mathrm{PO}_{3} \mathrm{H}_{2} \\
\text { Neutral } \\
\text { Negative }\end{array}$ & 206 & HEDP \\
\hline $\begin{array}{c}\text { 2-phosphono } 1,2,4 \\
\text { butane tricarboxylic } \\
\text { acid }\end{array}$ & 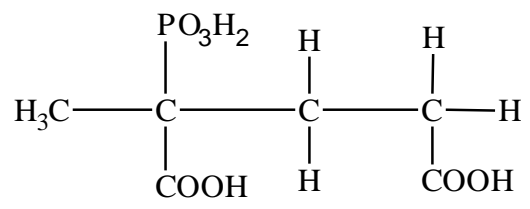 & $\begin{array}{l}-\mathrm{COOH} \\
-\mathrm{PO}_{3} \mathrm{H}_{2} \\
\text { Negative }\end{array}$ & 270 & PBTC \\
\hline $\begin{array}{l}\text { Polyamino polyether } \\
\text { methylene phosphonic } \\
\text { acid }\end{array}$ & $\begin{array}{c}\left(\mathrm{H}_{2} \mathrm{O}_{3} \mathrm{P}-\mathrm{CH}_{2}\right)_{2}-\mathrm{N}- \\
\mathrm{CH}\left(\mathrm{CH}_{3}\right) \mathrm{CH}_{2}- \\
\left(\mathrm{OCH}_{2} \mathrm{CH}\left(\mathrm{CH}_{3}\right)_{n}-\mathrm{N}-\left(\mathrm{CH}_{2}-\right.\right. \\
\left.\mathrm{PO}_{3} \mathrm{H}_{2}\right)_{2}\end{array}$ & $\begin{array}{c}-\mathrm{PO}_{3} \mathrm{H}_{2} \\
-\left(\mathrm{O}-\mathrm{CH}_{2}-\mathrm{CH}_{2}\right) n- \\
\text { Negative } \\
\text { Neutral }\end{array}$ & $600-630$ & PAPEMP \\
\hline
\end{tabular}

\section{Experimental}

Stock solutions of calcium chloride, magnesium chloride, sodium chloride, and sodium sulfate were prepared by dissolving known amounts of reagent grade chemicals in distilled water. Sodium bicarbonate solution was made fresh for copper stabilization experiments. Stock solutions ( $0.1 \%$ active solids) of phosphonate were prepared by dissolving known 
amount of phosphonates in distilled water. The $\mathrm{pH}$ of phosphonates solutions was adjusted to 8.00 using sodium hydroxide.

A known amount of stock solution $(100 \mathrm{mg} / \mathrm{L})$ of $\mathrm{Cu}\left(\mathrm{NO}_{3}\right)_{2}$ was added to known volume of synthetic tap water containing varying amounts of phosphonate stock solution in a $125 \mathrm{~mL}$ glass bottle. The synthetic tap water was prepared by mixing stock standard solutions of calcium chloride, magnesium chloride, sodium sulfate, sodium chloride, and sodium bicarbonate. The synthetic water composition was $100 \mathrm{mg} / \mathrm{L} \mathrm{Ca}^{2+}, 30 \mathrm{mg} / \mathrm{L} \mathrm{Mg}^{2+}$, $314 \mathrm{mg} / \mathrm{L} \mathrm{Na}^{+}, 192 \mathrm{mg} / \mathrm{L} \mathrm{SO}_{4}^{2-}, 571 \mathrm{mg} / \mathrm{L} \mathrm{Cl}^{-}$, and $60 \mathrm{mg} / \mathrm{L} \mathrm{HCO}_{3}^{-}$. After the addition of $\mathrm{Cu}^{2+}$ solution to the synthetic water, the $\mathrm{pH}$ of the solution was adjusted to 8.00 with dilute sodium hydroxide. The experimental solutions were kept at room temperature $\left(23^{\circ} \mathrm{C}\right)$ without stirring. At known time the solutions were filtered through a $0.22 \mu \mathrm{m}$ membrane filter and filtrate analyzed for copper by colorimetric method [10].

The performance of the stabilizing agent for $\mathrm{Cu}$ (II) ions was calculated according to the following equation:

$$
S(\%)=\left([\mathrm{Cu}]_{\text {sample }}-[\mathrm{Cu}]_{\text {blank }}\right) /\left([\mathrm{Cu}]_{\text {initial }}-[\mathrm{Cu}]_{\text {blank }}\right) \times 100 \%
$$

where:

$\begin{array}{lll}S & = & \text { Stabilization, } \% \\ {[\mathrm{Cu}]_{\text {sample }}} & = & \text { Cu concentration in the presence of phosphonate at } 1 \mathrm{hr} \\ {[\mathrm{Cu}]_{\text {blank }}} & = & \mathrm{Cu} \text { concentration in the absence of phosphonate at } 1 \mathrm{hr} \\ {[\mathrm{Cu}]_{\text {initial }}} & = & \mathrm{Cu} \text { concentration in the beginning of experiment at } 0 \mathrm{hr}\end{array}$

\section{Results and Discussion}

In aqueous solution depending on the water chemistry, copper(II) forms a variety of both soluble and insoluble complexes. The term stabilization used in this paper refers to an ability of the phosphonate to form soluble complexes, inhibit formation of hydroxo complexes, and/or dispersion [11]. In practice, it may be difficult to differentiate between truly soluble and very finely dispersed particles. Under the conditions employed in the present investigation, \% stabilization is defined as that concentration of the ionic species that is not removed by filtration through $0.22 \mu \mathrm{m}$ filter. On the other hand, dispersants function by de-agglomerating the preformed suspended matter (i.e., clay, iron oxide, zinc oxide, manganese oxide, titanium oxide, silica, calcium carbonate). Closely related to dispersion is crystal habit modification of scale forming salts (i.e., calcium carbonate, calcium sulfate dihydrate, calcium fluoride, calcium phosphate). In this process, the morphology of growing crystals is modified and extent of crystal growth is diminished, thereby delaying the settling of crystals. The term chelation, complexation, and sequestration is generally applied to phenomena where metal ions or complex species are maintained as soluble species in aqueous system.

Using the experimental conditions outlined above, a series of experiments was conducted to evaluate the performance of polymers as $\mathrm{Cu}^{2+}$ stabilizing additives. The 
experiments were designed to test the efficacy of phosphonates as a function of time, solution $\mathrm{pH}$, phosphonate dosage, and phosphonate architecture. Table 1 lists the phosphonates tested in the present study. Experiments were run in duplicate/triplicate and showed good reproducibility $( \pm 7 \%)$.

\section{Effect of time on $\mathrm{Cu}$ (II) precipitation}

Figure 2 presents $\mathrm{Cu}(\mathrm{II})$ stabilization data collected, at $\mathrm{pH} 8.0,25^{\circ} \mathrm{C}, 0$ and $15 \mathrm{ppm}$ PAPEMP. It is evident that $\mathrm{Cu}$ (II) precipitation increases or $\mathrm{Cu}(\mathrm{II})$ solution concentration decreases with increasing time. For example, residual $\mathrm{Cu}$ (II) present in the absence of PAPEMP at $15 \mathrm{~min}$ is $2.9 \mathrm{mg} / \mathrm{L}$ compared to $10 \mathrm{mg} / \mathrm{L}$ at $t=0 \mathrm{~min}$. As illustrated in Figure 2, further increase in time by twofold (i.e., 15 to $30 \mathrm{~min}$ ) results in $\sim 95 \%$ precipitation and $>99.8 \%$ precipitation (or $<0.02 \mathrm{ppm}$ residual $\mathrm{Cu}(\mathrm{II})$ ) is achieved at $60 \mathrm{~min}$ and at $2 \mathrm{hr}$ precipitation is essentially complete. As shown in Figure 2, similar $\mathrm{Cu}$ (II) residual concentration vs. time profile is also observed in the presence of $15 \mathrm{ppm}$ PAPEMP.

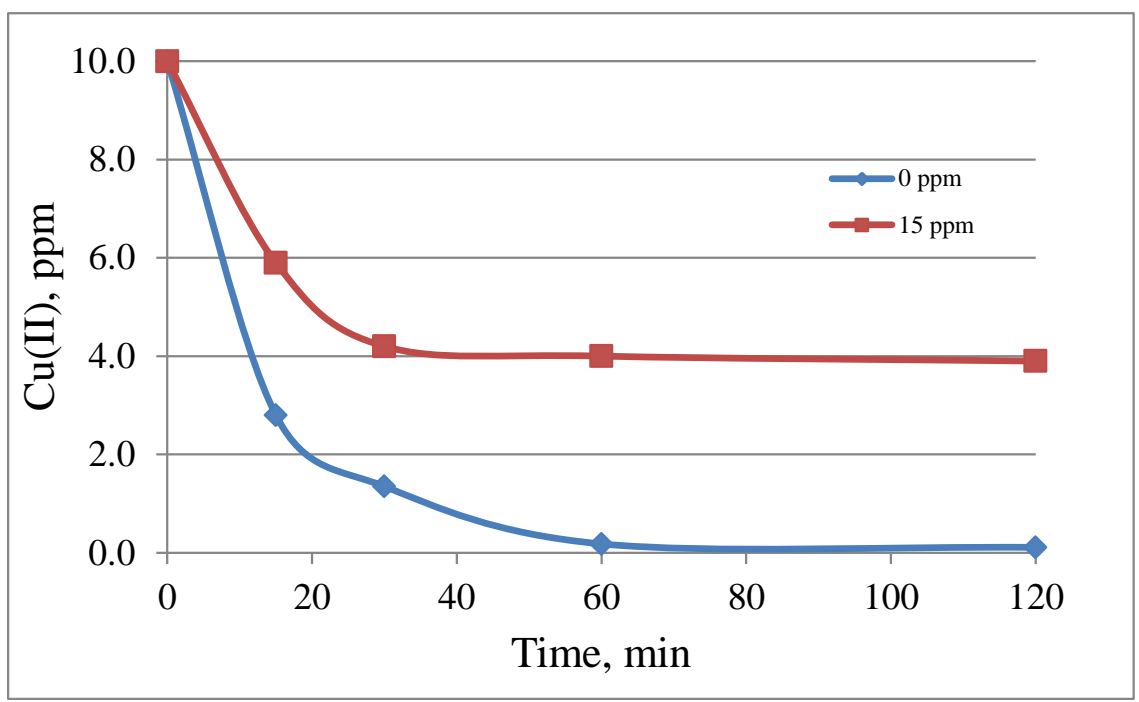

Figure 2. Residual $\mathrm{Cu}(\mathrm{II})$ ions concentration as a function of time in the presence of 0 and $15 \mathrm{ppm}$ of PAPEMP (pH 8.00, $\left.23^{\circ} \mathrm{C}, 0.22 \mu \mathrm{m}\right)$.

\section{Effect of filter paper size}

It is generally agreed that both, dispersion (or de-agglomeration) of suspended particles and scale inhibition processes play important roles in the success of treatment program for cooling water system. Although many factors play a role in determining the rate of scale formation, one key aspect is maintaining the size of the particulates below a certain minimum [12]. According to Stoke's law, the settling rate of spherical particles is proportional to the square of its diameter in quite solution. Particles with less $0.1 \mu \mathrm{m}$ diameter will settle at about $1 / 20^{\text {th }}$ the rate of $0.45 \mu \mathrm{m}$ particles, if no secondary effects are operative. In addition, rapid growth of particles can occur after a certain critical diameter is reached [13]. Polymeric inhibitors serve to limit particle size, thereby controlling 
additional growth. To study the impact of phosphonates on the growth of $\mathrm{Cu}$ (II) hydroxide particles, a series of experiments were carried out in which different filter paper size was used to filter the solutions. As indicated in Table 2, residual $\mathrm{Cu}$ (II) concentration strongly depends on filter paper size. For example, \%stabilization values obtained in the presence of 0.22 and $0.45 \mu \mathrm{m}$ filter papers are 45 and $65 \%$ compared to $80 \%$ obtained in the presence of $3 \mu \mathrm{m}$ filter paper. In the following sections we report results collected using $0.22 \mu \mathrm{m}$ filter papers.

Table 2. Particle size effects on the stabilization of $\mathrm{Cu}(\mathrm{II})$ hydroxide in the presence of $15 \mathrm{ppm}$ HPA.

Filter Paper Size $(\mu \mathrm{m})$

0.22

0.45
$\%$ Stabilization

45

66

80

89

\section{Effect of solution pH on Cu(II) ions precipitation}

In order to investigate the influence of solution $\mathrm{pH}$ on $\mathrm{Cu}(\mathrm{II})$ precipitation a series of experiments was carried out in the absence of phosphonate and at varying solution $\mathrm{pH}$ values. Results collected as a function of time and presented in Figure 3 clearly show that in the $\mathrm{pH}$ range 6.0 to $9.0, \mathrm{Cu}$ (II) precipitation strongly depends on solution $\mathrm{pH}$. The data presented in Figure 3 also reveal that precipitation reaction increases with increasing $\mathrm{pH}$ from 6.0 to 8.0 and decreases thereafter as the $\mathrm{pH}$ is increased from 8.0 to 9.0. Figure 4 presents comparative \% stabilization data collected at $1 \mathrm{hr}$ for experiments carried out in the presence of 0 and $20 \mathrm{ppm}$ of PAPEMP. It is evident that similar $\mathrm{pH}$ dependence of $\%$ stabilization values in the presence and absence of PAPEMP.

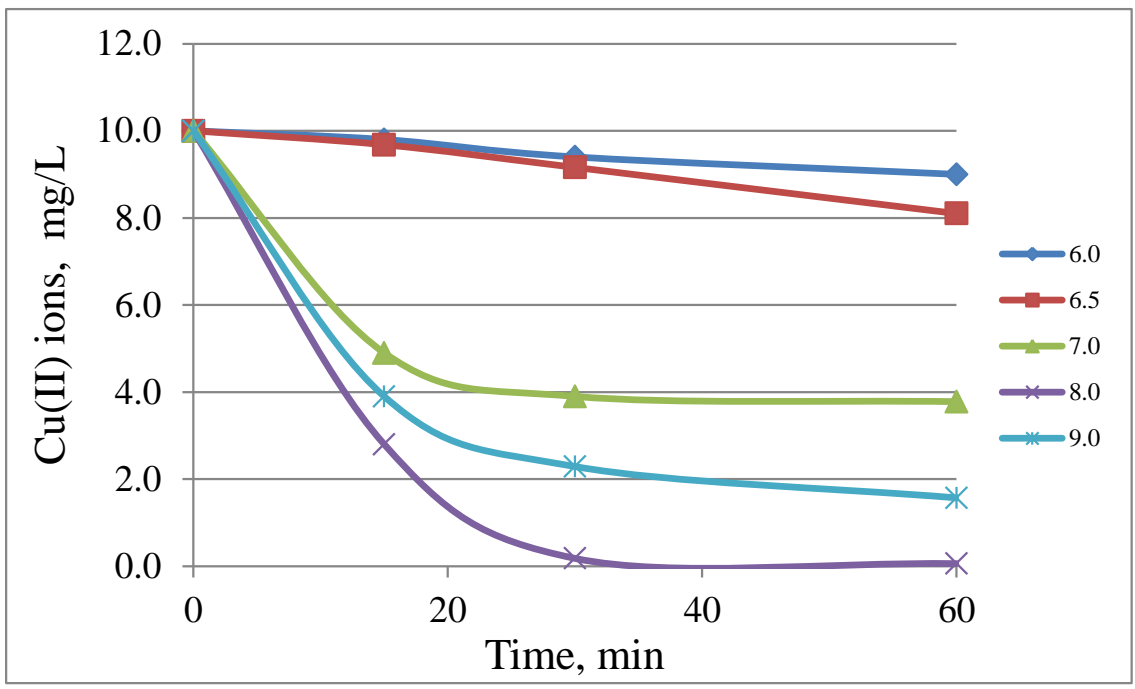

Figure 3. Effect of solution $\mathrm{pH}$ on $\mathrm{Cu}(\mathrm{II})$ ions stabilization as a function of time ( $\mathrm{pH} 8.0$, $\left.23^{\circ} \mathrm{C}, 0.22 \mu \mathrm{m}\right)$. 


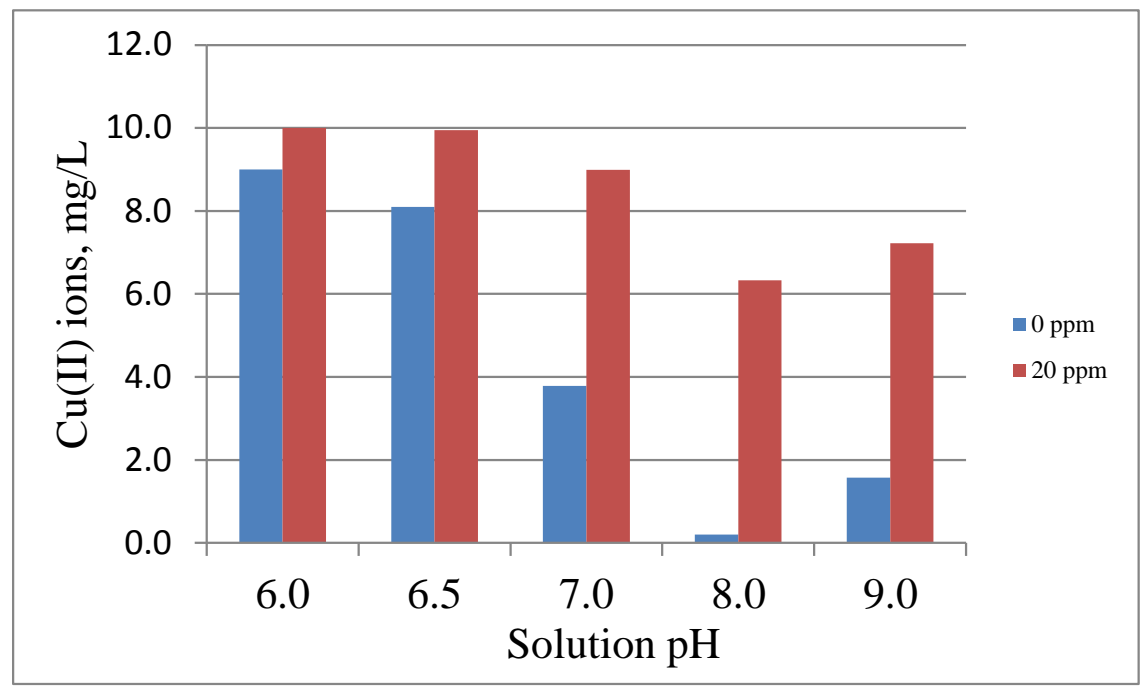

Figure 4. $\mathrm{Cu}(\mathrm{II})$ ions stabilization in the presence of 0 and $20 \mathrm{ppm}$ of PAPEMP $\left(23^{\circ} \mathrm{C}, 1 \mathrm{hr}\right.$, $0.22 \mu \mathrm{m})$.

\section{PAPEMP Performance}

The influence of phosphonate dosage on the stabilization of $\mathrm{Cu}(\mathrm{II})$ ions was investigated by carrying out a series of experiments in the presence of varying dosages of PAPEMP. Results presented in Figure 5 show that PAPEMP exhibits poor stabilizing ability at low dosages. For example, $\% S$ value obtained in the presence of $5 \mathrm{ppm}$ of PAPEMP1 is $10 \%$. Figure 3 also shows that increasing the phosphonate concentration from $5.0 \mathrm{ppm}$ to 15.0 ppm results in a significant increase (from 10 to 54\%) in $\% S$ values. It is worth noting that further increase in PAPEMP dosage increases the $\% S$ values and $>90 \% S$ value is obtained at $40 \mathrm{ppm}$ of PAPEMP. It is also interesting to note that $\% \mathrm{~S}$ vs. PAPEMP dosage profile observed in the present study has also been observed for $\mathrm{Cu}$ (II) stabilization by polymeric stabilizing agents [11].

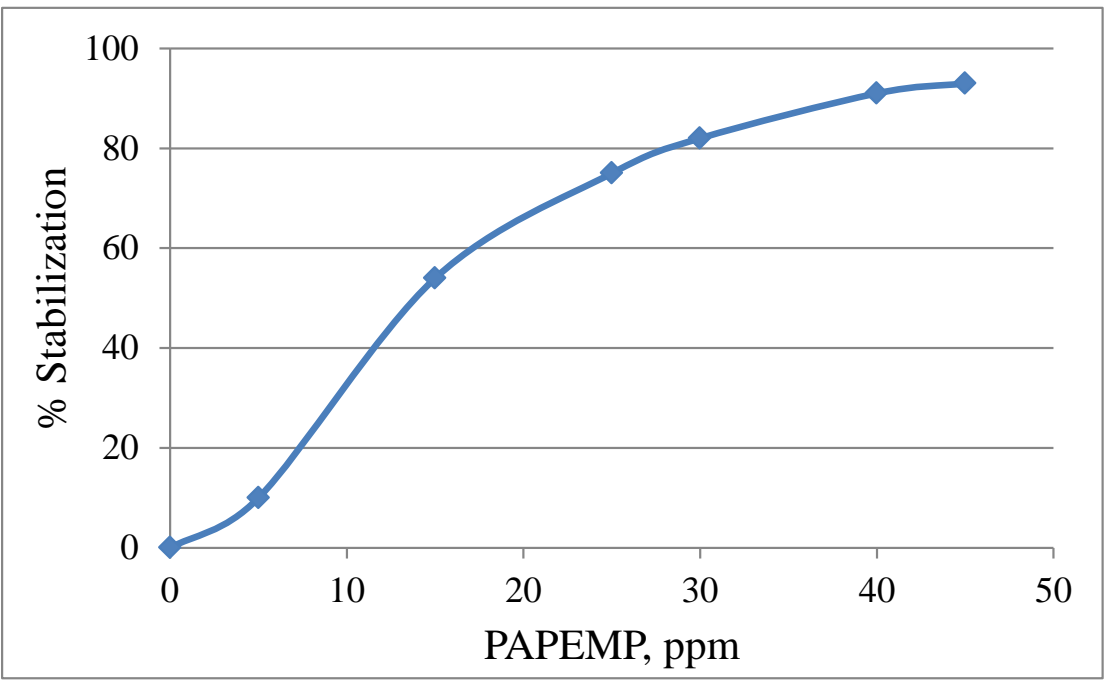

Figure 5. \% stabilization of $\mathrm{Cu}$ (II) ions in the presence of varying concentration of PAPEMP $\left(\mathrm{Cu}(\mathrm{II})\right.$ ions $\left.10 \mathrm{mg} / \mathrm{L}, 23^{\circ} \mathrm{C}, 1 \mathrm{hr}, 0.22 \mu \mathrm{m}\right)$. 


\section{Effect of Phosphonates Architecture on Cu(II) Ions Stabilization}

Currently, a variety of phosphonates containing different functional groups (i.e., $-\mathrm{PO}_{3} \mathrm{H}_{2}$, $-\mathrm{COOH},-\mathrm{OH},-\mathrm{CH}_{2}-\mathrm{O}-\mathrm{CH}\left(\mathrm{CH}_{3}\right)_{n}-$, see Table 1 for structures) are commercially available and are used to control corrosion and precipitation of scale forming salts, e.g., $\mathrm{CaCO}_{3}, \mathrm{CaSO}_{4} \cdot 2 \mathrm{H}_{2} \mathrm{O}, \mathrm{Ca}_{5}\left(\mathrm{PO}_{4}\right)_{3} \mathrm{OH}$, in industrial water treatment systems. It has been well documented that performance of phosphonates strongly depends on the type of phosphonate and scale being inhibited $[14,15,16]$. To study the effect of phosphonate architecture as $\mathrm{Cu}$ (II) stabilization agents a series of experiments were carried under similar experimental conditions $\left(\mathrm{pH} 8.00,1 \mathrm{hr}, \quad 0.22 \mu \mathrm{m}, 23^{\circ} \mathrm{C}\right)$. In order to study the impact of phosphonate architecture on $\mathrm{Cu}$ (II) stabilization, a series of experiments were carried out in the presence of varying dosages of various phosphonates. Results presented in Figure 6 clearly show that phosphonate performance as $\mathrm{Cu}$ (II) stabilizing agent strongly depends on phosphonate dosage and type and number of functional groups present in the phosphonate. As illustrated in Figure 6, increasing the phosphonate dosage results in gradual increase in phosphonate performance.

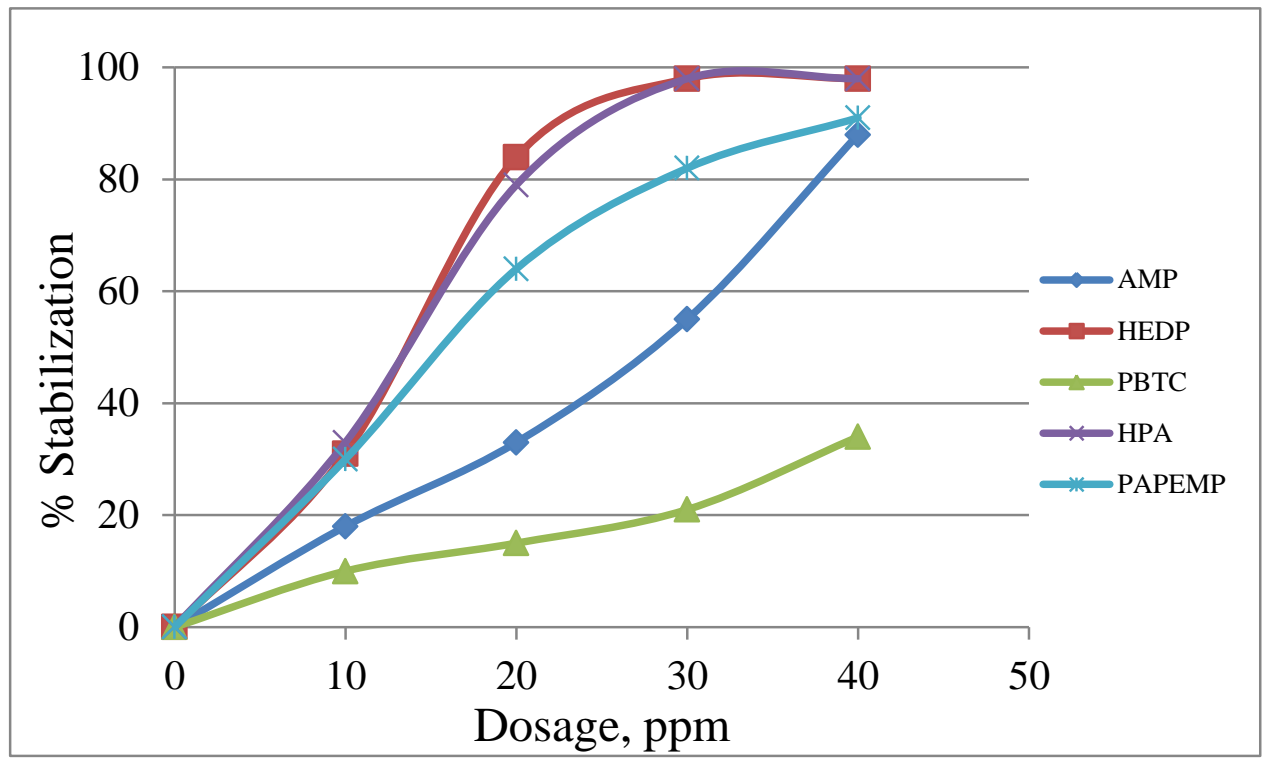

Figure 6. \% stabilization of $\mathrm{Cu}(\mathrm{II})$ ions in the presence of varying concentration of phosphonates $\left(\mathrm{Cu}(\mathrm{II})\right.$ ions $\left.10 \mathrm{mg} / \mathrm{L}, 23^{\circ} \mathrm{C}, 1 \mathrm{hr}, 0.22 \mu \mathrm{m}\right)$.

Table 3 summarizes the performance data for all phosphonates at 20 and $40 \mathrm{ppm}$ collected at $1 \mathrm{hr}$. Also, shown in Table 3 are the type and number of functional groups present in the phosphonates. It is clear that among the various phosphonates tested, PBTC shows the poor performance indicating that $-\mathrm{PO}_{3} \mathrm{H}_{2}$ and/or $-\mathrm{COOH}$ groups are not effective in stabilizing $\mathrm{Cu}(\mathrm{II})$ in aqueous solution. It is interesting to note that presence of $-\mathrm{OH}$ group in combination with $-\mathrm{COOH}$ and $\mathrm{PO}_{3} \mathrm{H}_{2}$ groups present in HPA and HEDP markedly improves the performance of HPA and HEDP compared to PAPEMP, AMP, and PBTC. 
Table 3. Comparative performance data on various phosphonates.*

\begin{tabular}{cccc}
\hline Inhibitor & Functional Group & $\begin{array}{c}\text { \% Stabilization } \\
\text { at } \mathbf{2 0} \mathbf{~ p p m}\end{array}$ & $\begin{array}{c}\text { \% Stabilization } \\
\text { at } \mathbf{4 0} \text { ppm }\end{array}$ \\
\hline HPA & $-\mathrm{OH},-\mathrm{COOH}, \mathrm{PO}_{3} \mathrm{H}_{2}$ & 79 & 98 \\
AMP & $\mathrm{PO}_{3} \mathrm{H}_{2}$ & 33 & 88 \\
HEDP & $-\mathrm{OH}, \mathrm{PO}_{3} \mathrm{H}_{2}$ & 84 & 98 \\
PBTC & $-\mathrm{COOH},-\mathrm{PO}_{3} \mathrm{H}_{2}$ & 15 & 34 \\
PAPEMP & $-\mathrm{PO}_{3} \mathrm{H}_{2}$ & 64 & 91 \\
\hline
\end{tabular}

${ }^{*} \mathrm{pH} 8.00,23^{\circ} \mathrm{C}, 1 \mathrm{hr}, 0.22 \mu \mathrm{m}$.

Based on the data presented the phosphonates can be ranked in terms of decreasing effectiveness as follows:

$$
\begin{aligned}
& \text { At } 20 \text { ppm: HEDP } \approx \text { HPA }>\text { PAPEMP }>\text { AMP }>>\text { PBTC } \\
& \text { At } 40 \text { ppm: } \mathrm{HEDP} \approx \mathrm{HPA}>\mathrm{PAPEMP} \approx \mathrm{AMP}>>\mathrm{PBTC}
\end{aligned}
$$

\section{Cu(II) hydroxide particles stabilization by phosphonates}

Photographs of copper hydroxide particles collected on filter papers at the end of experiments are shown in Figure 7. It is evident that best results are obtained by HPA - the darker the blue color, the more $\mathrm{Cu}$ (II) hydroxide precipitated from aqueous solutions.

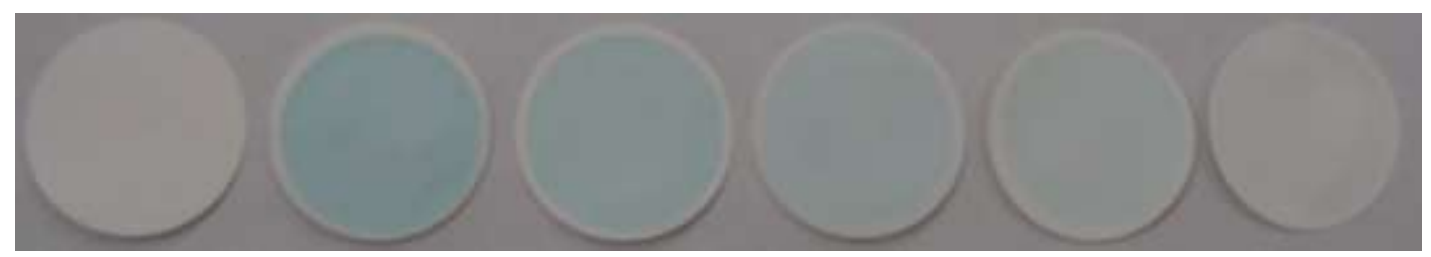
A
B
$\mathrm{C}$
$\mathrm{D}$
$\mathrm{E}$
$\mathrm{F}$

Figure 7. Photographs of $\mathrm{Cu}(\mathrm{II})$ hydroxide precipitated: filter paper (A), in the absence of phosphonate (B) and in the presence of 20 ppm of phosphonates: PBTC (C), AMP (D), PAPEMP (E), HEDP (F).

\section{Summary}

The results presented in this study support the following conclusions on the influence of phosphonates containing different functional groups in stabilizing $\mathrm{Cu}$ (II) ions in aqueous solutions:

- $\mathrm{Cu}$ (II) hydroxide formation strongly depends on solution $\mathrm{pH}$ and reaction time.

- $\mathrm{Cu}(\mathrm{II})$ ions stabilization by phosphonates increases with increasing phosphonate concentration. 
- Phosphonate performance as $\mathrm{Cu}$ (II) ions stabilization agent strongly depends on phosphonate architecture.

- Among the various phosphonates tested, phosphonates containing $-\mathrm{OH}$ and $\mathrm{PO}_{3} \mathrm{H}_{2}$ (i.e., HPA, HEDP) shows the best performance.

- Based on the data presented, the order of polymer performance in terms of decreasing performance is: HEDP $\approx \mathrm{HPA}>$ PAPEMP $>$ AMP $>>$ PBTC .

\section{Acknowledgement}

The author thanks Walsh University for support to carry out this investigation.

\section{References}

1. S. K. Hamdona, R. B. Nesim and S. M. Hamza, Desalination, 1993, 94, 69.

2. M. P. C. Weijen and G. M. Rosmalen, Desalination, 1985, 54, 239.

3. Z. Amjad, D. Butala and J. Pugh, CORROSION/99, NACE International, Houston, TX, 1999, paper no. 118.

4. S. B. Ahmed, M. Tlili, M. B. Amor, H. B. Bacha and B. Elleuch, Desalination, 2004, 167, 311.

5. W. Y. Shih, J. Gao, A. Rahardianto, J. Glater, Y. Cohen and C. H. Gabelish, Desalination, 2006, 196, 280.

6. S. E. Ghazi, A. A. El-Asmy and A. M. El-Norkashy, Ind. J. Sci. Technol., 2008, 1, no. 6,1 .

7. B. Domogalla, US Patent 2734028 (1956).

8. Z. Amjad, Materials Performance, 2013, 52, no. 12, 62.

9. Z. Amjad, Tenside Surfactants Detergents, 2007, 44, no. 4, 202.

10. Method No. 8506, HACH Company, Loveland, CO, USA.

11. Z. Amjad, Materials Performance, 2013, 52, no. 3, 50.

12. K. P. Fivizzani, L. Dubin, B. Fair and J. E. Hoots, CORROSION/89, NACE, Houston, TX, 1989, paper no. 433.

13. Particle Size Analysis, Eds. J. D. Stockham and E. G. Fochtman, Ann Arbor Publishers, 1977, pp. 45-55.

14. Z. Amjad, Int. J. Corros. Scale Inhib., 2014, 3, no. 2, 89.

15. Z. Amjad, R. T. Landgraf and J. L. Penn, Int. J. Corros. Scale Inhib., 2014, 3, no. 1, 35.

16. Z. Amjad, Langmuir, 1987, 3, 1063. 